


\section{ספר \\ תַבְבְִית הִיכָל}

הלא הוא

\section{קונקורדנציא קטנה עברית וארמית

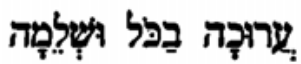 \\ לספרי תורה נביאים וכתובים. \\ יפיל}

כל השרשים והמלים שבאו כבר בהקונקורדנציות הראשונות,

ובהם נמלאו אלםי החסרונות וההשמטות ונתקנו כל המקֶוּתות והשניאות הרבות,

נם מראי המקומות נעשו בכדיקה יתֵרה ובצמצום נדול;

תוספות כל מלות השמוש והציחט, שלא בא זכרן בהקונקורדנציות הראשונות;

חִבור כולל כל מלות הגוף למיניהן ולנטיותיהן;

ספר כולל שמות עצמים פרטים למיניתם, איש לא נעדר.

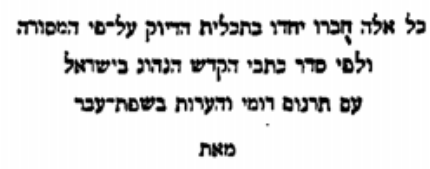

מאת

ד'ר שלמה מאנדעלקערן.

$$
\text { ליפסיא }
$$

בהוצאת פיימ :שותפיו (העררמאן קרעדנער) 


\title{
VETERIS TESTAMENTI
}

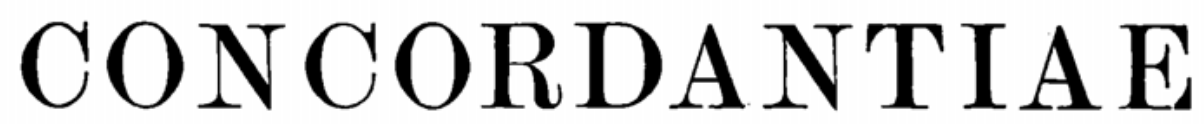

HEBRAICAE ATQUE CHALDAICAE

\author{
QUIBUS CONTINENTUR \\ CUNCTA QUAE IN PRIORIBUS CONCORDANTIIS REPERIUNTUR VOCABULA \\ LACUNIS OMNIBUS EXPLETIS \\ Particulae, PRONOMINA, NOMina PROPRIA \\ SEPARATIM COMMEMORATA
}

BEIVATO TEXTU MASORETICO LIBRORUMQUE SACRORUM ORDINE TRADITO

SUMMA CURA COLLLGIT E'T CONCINNAVIT

SOLOMON MANDELKERN

PHIL. ET JUR. DOCTOR

EDITIO MINOR EXEMPLIS OMISSIS

LIPSIAE

VEIT ET COM P. 


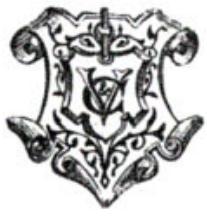

FX OFFIOINA GUILELMI DRUGULYNI LIPBIENBIS 